\title{
The Narrative of Women in Prison: The Parenting Practices and the Concepts of Mother in Incarcerated Women
}

\section{Ulya Saida, ${ }^{1}$ Elizabeth Kristi Poerwandari 2}

Universitas Indonesia, Depok - Indonesia

Corresponding Author: Ulya Saida, email: ulya.saida@ui.ac..id, Jl.Margonda Raya, Pondok Cina, Beji, Depok, Jawa Barat 16424

\begin{abstract}
This article discusses the experiences of incarcerated women regarding parenting practice in prisons and the concept of motherhood. With the narration of eight women who were pregnant or breastfeeding and serving their sentences at the Pondok Bambu Detention Center in East Jakarta, the researcher presented different viewpoints of women by listening to their stories even though they had committed criminal acts. This research uses a qualitative approach to gender perspective. The researchers did field observations during the data collection process. Parenting practices carried out in prison was not done without obstacles. There are obstacles in terms of knowledge as a mother, economic, and emotional side experienced by incarcerated women. These obstacles influence the concept of thinking of imprisoned women regarding social construction to be a good mother. They always try to look decent to be able to nurse their children with their conditions in prison. Some of them said the presence of their children in detention is like a new spirit in their life.
\end{abstract}

\section{Keywords: imprisoned mother; incarcerated women; parenting; women in prison}

\begin{abstract}
Abstrak: Artikel ini membahas pengalaman para wanita narapidana terkait praktik parenting di lapas dan konsep menjadi ibu. Melalui penuturan delapan perempuan yang sedang hamil atau menyusui dan menjalani hukuman di Rutan Pondok Bambu, Jakarta Timur, peneliti menghadirkan sudut pandang yang berbeda tentang perempuan dengan mendengarkan cerita mereka meskipun telah melakukan tindak pidana. Penelitian ini dilakukan dengan pendekatan kualitatif berperspektif gender. Peneliti juga melakukan observasi lapangan selama proses pengumpulan data. Praktik parenting yang dilakukan di lapas bukan dilakukan tanpa hambatan. Terdapat kendala pengetahuan sebagai ibu, sisi ekonomi, dan emosional yang dialami oleh para perempuan narapidana yang mempengaruhi konsep pemikiran perempuan narapidana mengenai konstruksi sosial untuk menjadi ibu yang baik. Mereka selalu berusaha berpenampilan layak untuk dapat mengasuh anaknya dengan kondisi di lapas. Beberapa di antara mereka mengatakan bahwa kehadiran anaknya di penjara seperti semangat baru dalam hidup mereka.
\end{abstract}

Kata Kunci: $\quad$ ibuyang dipenjara; wanita yang dipenjara; mengasuhanak; wanita di penjara 


\section{A. Introduction}

When we hear the word prison, what comes to our mind are things that are scary and full of crime. Crime acts in Indonesia are various, from the misuse of prohibited goods (drugs) to murder cases. Both men and women can do this act.

One of the examples is the case of Riany Wijaya, an inmate in Prison Class IIB of Women-Children Tangerang. She was imprisoned on the narcotic cases and caught after consuming methamphetamine with three friends. Riany was sentenced less than the maximum sentence of twenty years in prison. She felt grateful for the verdict, and also felt emotional when the judge was kind to her after the trial. When she shook hands with the judge and thanked him, the judge gave her a small amount of money to live in prison.

She was pregnant, and the baby was born while her previous detention in Prison Pondok Bambu was still running. When her baby was still in her womb, Riany was worried about the labor costs that she needs in the next few months. In her confusion, there was an offer from Mami (a woman outside the prison) to cover all the costs of Riany's labor. In return, the baby would later be taken by Mami. Riany was also promised to be given twenty-five million rupiahs if she was willing to give the baby to Mami. However, Riany did not believe in Mami, and she was worried that her baby would not be well taken care of, and the baby would be sold to other people. Riany decided to take care of her baby in prison and prefer to owe six million rupiahs from other people.

At the moment, Riany said that her husband or relatives had never visited her after being transferred to the Prison Class IIB of Women-Children Tangerang. While at the Pondok Bambu Detention Center, Riany supported her daughter by working as a laundry worker for the other prisoners. From this job, she got Rp. 50,000 per week. She used the money to buy milk and diapers for her baby. However, the money she earned was not enough for the daily needs of herself and her baby. The price of baby's necessities like formula and diapers are not low. Despite the situation, she still tried to survive with the small income to meet her baby's needs. Some prisons provide the needs of baby formula, diapers, or vitamins. Yet, it would only be fulfilled if, in a specific year, the prison had a particular budget for pregnant and breastfeeding women. 
Beatrice also felt pregnancy, childbirth, breastfeeding, and raising children in custody. Beatrice was a twenty years old woman in Prison Class IIB of Women-Children Tangerang. Beatrice was too young and had a one year five months old child. Beatrice was no more than eight-ten years old when the police arrested her. At that time, she was in her two weeks of pregnancy.

At the beginning of her time in custody, she was worried and often cried in depression when she had to imagine raising her child in prison. Beatrice said that raising a child in prison was hard; the facilities were inadequate and limited so that the process of caring for the womb while in prison was too tricky for her. She once had fallen from a chair she was on when she had to put something on a high shelf when she was three months pregnant. She was panicked, cried, and surrendered. She thought that she would have miscarried or the baby could not be saved, even if the baby survived, there might be something wrong in the physic of the baby. However, the baby was born safely after hard labor.

Beatrice's depression and trauma may also be experienced by other female prisoners in detention who are experiencing parenting processes. Not only depression or trauma during pregnancy, childbirth, or parenting, but also which happened in subsequent phases both when the woman is still in prison and when she has been released from prison. It will also be a particular concern for women in prison, especially with the concept of a good mother.

When she gave birth to her daughter, Beatrice was so scared and worried, since she had to undergo caesar surgery and did not have enough money. When the labor was getting closer, she was referred to a hospital close to the prison. However, Beatrice was rejected by the hospital since she only had BPJS. Then she was referred to another hospital and finally able to give birth, a normal delivery. Providing the needs of her child, such as formula and food, was also a particular obstacle for Beatrice. She relied on the generosity of the other fostered prisoners to support and helped her all the time.

Penitentiary and Detention Center in Indonesia are currently classified as overloaded (overcapacity). The lack of prison capacity, incomplete facilities to the poor service and the lack of ward staff causing the poor service for the prisoners. According to the Directorate General of Corrections, Ministry of Justice and Human Rights through a correctional database system, the number of male and female prisoners in Indonesia as of November 2019 amounted to 
264,801 people. The number of inmates increases, especially in female prisoners. Female prisoners, who initially numbered 7,000 in 2014, now reach 14,840. At the same time, male prisoners arrive 249,961 people. See Table 1.

Living life as a prisoner/convict is not an easy thing to do, especially for women, who have to undergo pregnancy while in the detention period, or who have a baby under the age of two years. The case of women prisoners/convicts taking care of their children in prison is not only experienced by Riany, but also experienced by many other women prisoners/convicts in various regions in Indonesia. There are many kinds of problems experienced by women prisoners/convicts.

The process of giving birth to taking care of the children is essentially not only the responsibility of the women. Still, it requires assistance from others, such as husband and kin family. However, this is not the case for female prisoners at the Class II Detention Center Pondok Bambu. Some of them who are pregnant or have given birth are taking care of their under two years old babies must struggle alone to meet their needs as women and the needs of their babies. In practice, the Government has not provided the accommodation of the requirements optimally. For example, in the case of Riany, who needed to do laundry labor for other prisoners with higher economic status than her. Class discrimination still occurs in correction facilities.

Table 1.

Number of Male and Female Prisoners and Convicts in Indonesia

\begin{tabular}{|c|c|c|c|c|c|c|c|c|c|c|c|c|c|c|}
\hline \multicolumn{7}{|c|}{ TAHANAN } & \multicolumn{7}{|c|}{ NAPI } & \multirow{2}{*}{$\begin{array}{l}\text { Tahanan } \\
\text { \&Narapida } \\
\end{array}$} \\
\hline $\mathrm{DL}$ & $\mathrm{DP}$ & TD & $\mathrm{AL}$ & $A P$ & TA & TOTAL & $\mathrm{DL}$ & $\mathrm{DP}$ & TD & $\mathrm{AL}$ & $A P$ & $\mathrm{TA}$ & TOTAL & \\
\hline 63.275 & 3.425 & 66.700 & 704 & 16 & 720 & 67.420 & 186.686 & $\mid 11.415$ & 198.101 & 1.942 & 40 & 1.982 & 200.083 & \begin{tabular}{|l|}
267.503 \\
\end{tabular} \\
\hline \multicolumn{2}{|l|}{ TDL: } & \multicolumn{5}{|c|}{$\begin{array}{l}\text { Tahanan Dewasa Laki-Laki } \\
\text { (Male Adult Prisoner) }\end{array}$} & & TDP: & & \multicolumn{5}{|c|}{$\begin{array}{l}\text { Tahanan Dewasa Perempuan } \\
\text { (Female Adult Prisoner) }\end{array}$} \\
\hline \multicolumn{2}{|l|}{ TAL: } & \multicolumn{6}{|c|}{$\begin{array}{l}\text { Tahanan Anak Laki-Laki } \\
\text { (Male Children Prisoner) }\end{array}$} & TAP: & \multicolumn{6}{|c|}{$\begin{array}{l}\text { Tahanan Anak Perempuan } \\
\text { (Female Children Prisoner) }\end{array}$} \\
\hline \multicolumn{2}{|c|}{ NDL: } & \multicolumn{5}{|c|}{$\begin{array}{l}\text { Napi Dewasa Laki-Laki } \\
\text { (Male Adult Convict) }\end{array}$} & & NDP: & \multicolumn{6}{|c|}{$\begin{array}{l}\text { Napi Dewasa Perempuan } \\
\text { (Female Adult Convict) }\end{array}$} \\
\hline \multicolumn{2}{|l|}{ NAL: } & \multicolumn{5}{|c|}{$\begin{array}{l}\text { Narapidana Anak Laki-Laki } \\
\text { (Male Children Convict) }\end{array}$} & & NAP: & \multicolumn{6}{|c|}{$\begin{array}{l}\text { Narapidana Anak Perempuan } \\
\text { (Female Children Convict) }\end{array}$} \\
\hline
\end{tabular}

Source: Detention Database System 
Article 20 Government Regulation No. 32 of 1999 about the requirements and the procedures of the implementation of fostered prisoners of correctional institutions states that: 1) Prisoners and Correctional Protege who are sick, pregnant, or breastfeeding, have the right to supplementary food according to doctor's instructions. 2) Supplemental food is also given to prisoners who do certain types of work. 3) Children of a female prisoner who are taken into the prison or born in the prisons can be given supplementary food according to doctor's instructions, up to the age of 2 (two). 4) In the case of the child, as referred in paragraph (3) has reached the age of 2 (two), the child must be handed to his father or relatives or other parties with the consent of his mother and made in one statement report. 5) For the benefit of the children's health, the correctional institution may determine supplementary food as referred in paragraph (3) based on the doctor's consideration.

Nevertheless, not many women prisoners/convicts received appropriate rights. Law number 12 of 1995 about penitentiary states that prisoners must receive guidance in correctional institutions (prisons). In that guidance, many aspects must be fulfilled, one of which is health. At present, there is no specific fund for the reproductive health of female prisoners. Female prisoners should have the right to get privileges, such as the fund for special needs such as sanitary napkins.

Furthermore, Article 14 of Law number 12 of 1995 about Corrections, states that prisoners have the right to 1) worship according to their religion or beliefs; 2) receive care, both spiritual and physical custody; 3 ) get education and teaching; 4) get proper health services and food; 5) make a complaint; 6) get reading material and keep up with mass media broadcasts which are not prohibited; 7) get a wage or premium for the work done; 8) have family visits, legal counsel, or certain other people; 9) get a reduced sentence (remission); 10) get assimilation opportunities including family visit leave; 11) get parole; 12) has to leave right before free, and 13) get other rights under applicable laws and regulations.

However, not all the rights, as mentioned in the article, are recognized and applied. The childcare process carried out in the prisons is undoubtedly dependent on the fulfillment of the rights of female prisoners, especially at point (d), which is getting proper health services and food. But, from the example 
experienced by Riany, the policy has not been done. It is indeed ironic that it happened to female prisoners. Correctional law and its regulations of implementation have not adopted those matters. There are many injustices for women in prison; even though they are prisoners, there should be concepts about their health rights that must be implemented. For example, from the aspect of nutrition for pregnant prisoners, there should be regular checks on their health conditions. Besides, if necessary, the detention center can also provide ultrasound equipment, activities in the detention center that is more friendly to pregnant women, care to the conditions of beds for pregnant prisoners, which must be comfortable. Another health aspect can be seen from the number of bathrooms provided in detention centers. The number of bathrooms should be adjusted according to the number of prisoners-many prisoners have to queue up early every day to use the toilets. Not to mention when the water is not flowing well, which will be difficult for the prisoners, especially those who are menstruating, it can disrupt the reproductive system and function in women.

Female prisoners/convicts are among the most vulnerable group in society. According to Dawn K. Cecil, women in prison categorized as sensitive and invisible populations. ${ }^{1}$ Not only being a woman makes someone often get ignored since they are not the majority population in a correctional institution, but she (woman) is also vulnerable in facing violations of human rights due to community viewpoint and the justice system which are full of gender bias and dominated by patriarchal thought.

Law number 12 of 1995 has not been changed for a long time since it is considered relevant and does not yet regulate the legal protection for female prisoners. The law only states about prisoners in general and does not distinguish explicitly between male and female prisoners. ${ }^{2}$

Not to mention the condition of female prisoners/convicts in prison, which sometimes does not get any special attention in the justice system. Gender issues that illustrate the reality of women's lives and matters relating to women's lives in prisons, especially regarding parenting, are rarely discussed.

\footnotetext{
${ }^{1}$ Frances Heidensohn, "Gender and Crime," in The Oxford Handbook of Criminology, ed. M. Maguire, R. Morgan, and R. Reiner, Oxford Handbooks (Oxford: The Oxford University Press Incorporated, 2007).

${ }^{2}$ Komnas Perempuan, Pemetaan Kekerasan terhadap Perempuan dalam Tahanan dan Serupa Tahanan, 2011.
} 
Female prisoners need obstetric services (services regarding pregnancy and birth), gynecology (issues regarding women reproduction system), and support in carrying out their role as parents. ${ }^{3}$ This often does not exist in the correctional system in Indonesia.

Conducting parenting activities in prisons is undoubtedly different from the parenting process outside the prison with healthy and supportive environmental conditions. Women prisoners only were given at least two years to care for their newborn children, but they are not allowed to bring children who are more than two years old. Maria Montessori, a well-known early childhood education figure, states that in the age range from birth to 6 years old, children experience a golden age, a period when children begin to be sensitive to various stimuli. However, the Government does not accommodate this moment. The violence occurs since it separates the mother and her children.

The complexity of life experienced by women in prison is pleasing because crime and women are a new issue which is then attached to women. Women who are constructed both by gender and society to carry out the parenting process should continue to carry out the process in any circumstances and conditions, even in unsupportive parenting conditions. The role of the mother then becomes complex when it is juxtaposed with prison. In many cases, imprisoned mothers are the sole or primary caregivers for their children who noted as contributing factors to the poor outcomes experienced by children. ${ }^{4}$ There are $95 \%$ of children of incarcerated mothers moved from their family homes. They cared for either family or other relatives. Nursing or foster caregivers is a direct consequence of imprisoned mothers, where the disproportionately harmful levels of outcome usually occur.

Based on previous studies, the writer found seven previous studies that were relevant to the parenting of incarcerated mothers. The first studies have been done by Sinead O'Malley and Carmel Devaney, about maintaining the relationship between mother and children in the prison system in Ireland. The children of incarcerated mothers tend to experience changes in the caring process and face specific challenges when trying to visit their parents in prison, partly because of the lack of accompanying adults.

${ }^{3}$ J. E. Hitchcock, P. E. Schubert, and S. A. Thomas, Community Health Nursing: Caring in Action (New York: Thomson Learning Inc., 2003).

${ }^{4}$ O. Robertson, Women in Prison and Children of Imprisoned Mothers Series: The Impact of Parental Imprisonment on Children (Geneva: The Quaker United Nations Office, 2007). 
In particular, prisons in Canada, children can live with their mothers for two days a week so that mothers could do their parenting roles during the visit. Whereas in Indonesia, based on Law number 32 of 1999, it is stated that female prisoners could raise their children in prisons until the child is two years old, the age at which the children need exclusive breastfeeding on their mothers. Afterward, the child should be entrusted to other relatives or other caregivers according to based on the agreement with the mother.

Research about legal protection for pregnant female prisoners in Indonesia is also interesting to study to understand how women, especially pregnant women, are treated in prison through the legal aspects. Whether their rights are fulfilled or not, 5 it is also interesting to know about the reason why women can be in prison.

The term of crime is more attached to men, however, based on anthropological gender research. The reason for the average crime rate for women is lower than men are caused by several reasons: 1) Women are physically less strong. They also have distinctive psychological abnormalities, 2) Women are protected by their environment, such as the workplace, home; also, women drink less alcohol (Sumarauw). In general, the common crimes committed by women are kidnapping minors (Article 328 of the Criminal Code), abortion (Article 348 of the Criminal Code), abuse (Article 351 of the Criminal Code), theft (Article 362 of the Criminal Code), theft with incriminating (Article 363 of the Criminal Code), theft with violence (Article 365 of the Criminal Code), fraud (Article 378 of the Criminal Code) and narcotics (Law No. 22 of 1997).

This study uses the qualitative method. The data collected an in-depth interview with eight informants. They are mothers in prison, prison administrators, and social workers from external institutions who support female prisoners with their needs while in prison. A thematic analytical approach applied in this study. It is examining data to extract core themes that distinguished in the transcript. Thematic analysis is indeed a time-consuming process, but it is fit to identify bright ideas, makes it a useful approach. Therefore, the data relating to supporting themes and facilitating motherchildren relationships are extracted and analyzed. An overview of the analyzed

5Tirsa D.G Ticoalu, "Perlindungan Hukum pada Narapidana Wanita Hamil di Lembaga Pemasyarakatan.," Lex Crime Vol. II/No (2013). 
data and detailed results are sent electronically to each respondent with requests for feedback about the content.

The legal documents were collected, analyzed, and presented in descriptive qualitative analysis-interviewees conducted by visiting prison directly to be examined and to complete the data collected.

Research on female prisoners and their relationship with their children in prison in Ireland has revealed many examples of good practice. This research highlights the positive results of all parties involved in facilitating and developing positive relationships between mothers and their children. However, this good practice is supported well by the intentions of each practitioner. The efforts to maintain the relationship between mothers and their children are essential things to do. This research highlights the need for further study in the context of Irish prison to consider the needs between incarcerated parents and their children fully and to identify appropriate responses to the requirements.

The rights between female prisoners and male prisoners are the same; however, in this case, for female prisoners, some reasons should get particular treatment from male prisoners, which differ in several respects. It includes the nature of female prisoners than male prisoners do not have, such as menstruation, pregnancy, giving birth, and breastfeeding. Consequently, female prisoners need special attention both according to the law and from the prison officers.

The Government made regulations regarding the implementation of female prisoners' rights in Government Regulation No. 32 of 1999. Article 20 regulates the protection of female prisoners.

The research Kate Luther and Joanna Gregson explain that prison facilitates and controls women's ability to become parents for their children. In some states, imprisoned women live together and actively nurse their children through nursery programs. This research explores how those women experience the tense from being mothers and prisoners at the same time. Mothers must be someone who can make decisions about their children since mothers should know their children better than anyone else and that no one to direct their children's physical and social well-being. Lois ${ }^{6}$ stated that the dominant maternal ideology shows that "good" mothers know their children better than anyone else so that they could or should fulfill all their children's

6Jennifer Lois, "Emotionally Layered Accounts: Homeschoolers' Justifications for Maternal Deviance," Deviant Behavior 30, no. 2 (2009): 201-34, https://doi.org/10.1080/ 01639620802069783. 
individual needs. In the context of exploiting limited decision-making power, this study pays particular attention to how restrictions on childcare programs in prisons affect the ability of imprisoned mothers to direct the physical and social well-being of their children. Through observation and in-depth interviews, this study found that women in prisons experienced significant challenges when the roles of mothers and prisoners performed simultaneously. Specifically, this study found the detention of women as decision-making mothers and the limitation of their ability to create a sense of 'family' in the institution. ${ }^{7}$

Yunitri Sumarauw conducted the study about the female prisoners in prison. The research examined using a gender anthropology study, which took place at Class II Manado Detention. The result of this study, some informants did not realize they committed a crime in the form of violation of the law. They said that they were framed by their closest relatives, while they have broken the rule. Their law knowledge is limited, which makes them realize that their actions are illegal after the police arrest them.

The results of this study also indicate that prisoners or ex-convicts have proper human rights under the second principle of Pancasila. Besides, coaching in prison is the manifestation of prisoners in paying for the mistakes or violations of the law they have committed.

The next research is a study from Jenniffer Arnett Lee, explains the prisoners whose life is changing, and his freedom is taken over and controlled by the Government. Imprisoned women face additional burdens since there are gaps in detention. It shows that the detainee institution entrapped in the past gender stereotypes. ${ }^{8}$

The research shows that in the detention center, there are exceptions to male and female prisoners. Female prisoners receive fewer and less vocational and educational programs. Besides, female prisoners also have less access to health care in prisons. This research finds that there is a practice of segregation in the detainee center.

\footnotetext{
${ }^{7}$ Kate Luther and Joanna Gregson, "Restricted Motherhood: Parenting in a Prison Nursery," International Journal of Sociology of the Family 37, no. 1 (2011): 85-103, https://www. jstor.org/stable/23029788.

8Jenifer Arnett Lee, "Women Prisoners, Penological, Interest, and Gender Stereotypping: An Application of Equal Protection Norms to Female Inmates," HeinOnline, 2001, https://heinonline.org/HOL/LandingPage?handle=hein.journals/colhr32\&div=11\&id=\&page=.
} 
Another previous study by Judith S. Willison and Patricia O'Ben, shows the condition of women in the detention center of the United States. The research raises the issue of the reasons behind women committing a crime, which makes them arrested, ideologies, and the policies in the detention center, and the consequences of women's detention.

Women in the detention center described as having poor conditions such as being isolated from family and friends, experiencing physical health problems, and mental stress. Their access to care and treatment when they are sick and pregnant becomes limited, and experience sexual violence by prison officers. ${ }^{9}$

Another research Dawn K. Cecil, James McHale, Anne Strozier, and Joel Pietsch, describe a good parenting program for the children of women in detention. The nursing of the children whose mothers are in the detention center could be carried with a shared parenting method. This shared parenting method is carried out by involving the participation of other family members. In the research, the shared parenting method is carried out by including grandmother or another family member. The well-implemented method can bridge the women in the detention center to participate in the parenting process. The shared parenting method should is carried out under good communication between the imprisoned mothers with the foster caregiver who nurse the children. The dialogue established between mother and foster caregiver could be a medium for mothers to get involved in the parenting process. ${ }^{10}$

There are many studies about female prisoners/convicts; however, the studies explored more about law aspects, and criminological perspective, which are the reasons of many criminal acts are carried out by women or how the law treats women in stages/convicts. To date, there has been no research that specifically focuses on the practice of parenting and the concept of mothers in female prisoners/convicts. Furthermore, there are no studies that apply gender analysis to understand the struggle of female prisoners/convicts in childcare. Therefore, this study will examine the complexity of the struggle of female prisoners/convicts to carry out the role of mother in the detention center, especially related to parenting practices and the concept of motherhood.

9Judith S. Willison and Patricia O’Brien, "A Feminist Call for Transforming the Criminal Justice System," Affilia 32, no. 1 (2017): 37-49, https://doi.org/10.1177/0886109916658080.

${ }^{10}$ Dawn K. Cecil et al., “Female Inmates, Family Caregivers, and Young Children's Adjustment: A Research Agenda and Implications for Corrections Programming," Journal of Criminal Justice 36, no. 6 (2008): 513-21, https://doi.org/10.1016/j.jcrimjus.2008.09.002. 


\section{B. Method}

This research uses a qualitative approach with a gender perspective to explain the problem or issue that needs further exploration in a particular social context, through the research subject deals with the problems they face. This research uses the perspective of women who want to listen to women's voices. This research is a case study that analyzes a phenomenon specifically and deeply in a limited context (Bounded context). ${ }^{11}$

The researchers researched on the Class IIA Detention Center Pondok Bambu, East Jakarta, by taking eight detainees who registered as prisoners or convicts. The eight interviewees consisted of four women with children in prison, three women who were pregnant in prison, and one woman who had been pregnant and gave birth in prison but did not nurture her children in detention.

To obtain the illustration and understanding of the livelihoods of the informant, the researcher used in-depth interviews. The eight interviewees interviewed in a room inside Pondok Bambu Detention Center with a duration of 45 - 75 minutes. Interviews conducted using open-ended and flowing questions based on interview guidelines.

Data collection conducted with observation. Processing the data was done by putting them into transcripts of all interviews with the interviewees; this data coded to organize and systematize data completely. So that the data can bring up a picture of the topic being analyzed, thus the writer will be able to find the meaning of the data collected. The writer also uses thematic analysis to find the 'patterns' that the other party does not see clearly.

\section{Results and Discussion}

\section{Parenting Practice in Prison}

Baldwin said that women in prison are not a homogeneous group. A mother in prison described as having feelings of despair, anger, sadness, loss, frustration, guilt, and shame, even when they are in contact with their children. ${ }^{12}$ This feeling is closely related to the parenting practices they carry

\footnotetext{
11E. Kristi Poerwandari, Pendekatan Kualitatif: Penelitian Perilaku Manusia (Depok: Lembaga Pengembangan Sarana Pengukuran dan Pendidikan Psikologi (LPSP3), Fakultas Psikologi UI, 2007).

12Lucy Baldwin, "Motherhood Disrupted: Reflections of Post-Prison Mothers," Emotion, Space and Society 26 (2018): 49-56, https://doi.org/10.1016/j.emospa.2017.02.002.
} 
out in prison. Feminist experts and researchers who are often involved in the research about prison argue that prison is a dangerous space for women. Prison is a violent gender-based institution where power and control exist only to repeat the inequalities and challenges faced by women in broader society. ${ }^{13}$

Goffman ${ }^{14}$ argues that although the social control has already run in society, it is much more felt and present in the institutions of prisons, where unequal power relations between two groups and prison officials have restrictive control over other prisoners. This grouping is relevant to the consequences of feelings and emotions in prisons, which show that prison officials tend to feel superior and right. In contrast, the inmates feel inferior and weak, which, according to Goffman, results in the distance in society.

Table 2.

The Interviewee of the Research

\begin{tabular}{|c|c|c|c|c|c|c|c|c|}
\hline & 1 & 2 & 3 & 4 & 5 & 6 & 7 & 8 \\
\hline Name & Miftah & Yuni & Margaret & Asti & Nisa & Rina & Reska & Saras \\
\hline Age/yeras & 27 & 38 & 37 & 39 & 19 & 35 & 31 & 25 \\
\hline $\begin{array}{l}\text { Number of } \\
\text { Children }\end{array}$ & 3 & 8 & 4 & 6 & - & 2 & 3 & 2 \\
\hline Last Education & Diploma & $\begin{array}{l}\text { High } \\
\text { School }\end{array}$ & $\begin{array}{l}\text { High } \\
\text { School }\end{array}$ & $\begin{array}{l}\text { High } \\
\text { School }\end{array}$ & Junior High & Diploma & High School & Diploma \\
\hline Last Job & $\begin{array}{l}\text { Ministry } \\
\text { Staff }\end{array}$ & $\begin{array}{l}\text { House- } \\
\text { wife }\end{array}$ & Employee & Employee & Baby Sitter & Employee & House-wife & $\begin{array}{l}\text { Sales } \\
\text { Promotion } \\
\text { Girl }\end{array}$ \\
\hline $\begin{array}{l}\text { Detention } \\
\text { Period }\end{array}$ & $\begin{array}{l}3 \text { years } 6 \\
\text { months }\end{array}$ & $\begin{array}{l}5 \text { years } 3 \\
\text { months }\end{array}$ & $\begin{array}{l}5 \text { years } 3 \\
\text { months }\end{array}$ & $\begin{array}{l}4 \text { years } 3 \\
\text { months }\end{array}$ & $\begin{array}{l}1 \text { year } 9 \\
\text { months }\end{array}$ & $\begin{array}{l}\text { Not } \\
\text { convicted } \\
\text { yet }\end{array}$ & $\begin{array}{l}\text { Not convicted } \\
\text { yet (just } \\
\text { entered } 5 \text { days) }\end{array}$ & $\begin{array}{l}4 \text { years } 2 \\
\text { months }\end{array}$ \\
\hline $\begin{array}{l}\text { Ensnare } \\
\text { case }\end{array}$ & Fraud & Drugs & Fraud & Drugs & Theft & Fraud & Fraud & Drugs \\
\hline $\begin{array}{l}\text { The age of the } \\
\text { children }\end{array}$ & $\begin{array}{l}1 \text { year } 2 \\
\text { months }\end{array}$ & 1 year & 11 months & 1 month & $\begin{array}{l}\text { Pregnant } 8 \\
\text { Months }\end{array}$ & $\begin{array}{l}\text { Pregnant } 9 \\
\text { Months }\end{array}$ & $\begin{array}{l}\text { Pregnant } 5 \\
\text { months }\end{array}$ & $\begin{array}{l}\text { Taken } \\
\text { home and } \\
\text { nursed by } \\
\text { parents }\end{array}$ \\
\hline $\begin{array}{l}\text { Gender of the } \\
\text { children }\end{array}$ & Female & Male & Male & Female & - & - & - & Male \\
\hline
\end{tabular}

Source: Primary data (the names of the interviewee are not their real names)

${ }^{13}$ L. Moore and P. Scraton, The Incarcerated of Women: Punishing Bodies and Breaking Spirits (London: Palgrave Macmillan, 2014).

${ }^{14}$ Baldwin, "Motherhood Disrupted: Reflections of Post-Prison Mothers." 
Some of the mothers interviewed felt deep emotional, although the level depends on the culture and requirements of the prison itself. Mrs. Yuni thought that she received limited emotional support from the officers. However, this was not a universal experience, and the feeling of being in prison made the mothers feel "invisible" and "inadequate" from the viewpoint of the prison officials.

"Yes... sometimes there are such spoiled kids. There is a time here when it is time to open. So there is no use for us to beg for it first. For example, if we can do something inside, why should we bother ourselves, it is troublesome. They trouble us a lot. I think so. That is why for my child, yeah ... I said later, dear ... it has not been opened yet ... he can not talk yet, but we give some explanation. Later ... when it's opened, we will get out. Before it is opened, we ask them to play." (Mrs. Yuni/SU2/20/08/19)

The "superiority" makes Mrs. Yuni someone who is "weak" and "less decent," that illustrated when her child asks to leave the room when he is in a fussy state but wash old by Mrs. Yuni because it is not the right time to leave the room.

Unequal power relations in prison institutions, which are related to parenting practices, can be seen from the facilities owned by the inmates with middle to upper economic status. They will have no difficulty in doing the parenting process in prison. They will quickly get the money sent from outside the prison to buy milk and diapers and other necessities in prison. The prison provides food stall facilities that sell daily needs for the fostered prisoners. For those who do not have enough deliveries, they must work inside the prison. Most of the interviewees of this study conducted a korpe (working in prison) to fulfill their and their children's needs in the prison even though some of them received remittances from outside the prison, they continued to work. At the same time, those who are pregnant are not allowed to do korpe since the detention center does not want to take responsibility and take risks if something bad happens to the fostered people who conduct the korpe.

There is an interesting finding from this study, which is the existence of donors who greatly helps the practice of parenting in prison. Donors consist of people who donate milk, diapers, and clothing for babies in prison. Donors themselves are fostered citizens who are also serving their sentences. Thus, they are helped with the needs of their children while in prison. Based on the 
interview with the midwife who served in prison, they said that the detention center did not make the concept of this donor.

"Yes, maybe because there are a lot of them, that is why they are called donors or maybe because they give often. We do not know their interpretation. From our perspective (officers), the thought is to give money, so it does not matter to them to give diapers or clothes. It's from them for them because they care about their fellow men." (Mrs. Sukma/SU9)

The practice of parenting in prison connects with a mother's emotional feeling and anxiety over the inability to nurse their children in prison, which also one of the concerns associated with the practice of parenting in prison. However, there are a lot of people who support the practice of parenting in prison, especially friends of fostered citizens who participate happily in supporting the mothers to nurture their children in prison. The mutual cooperation is more visible in the cell/room of the mother-children, compared to the cell/common room. Usually, the help given is to help take care of the children when their mothers are taking a bath or doing other activities. If the mother does a korpe, other fostered prisoners will be willing to look after the child. However, not all mothers who bring children are happy to leave their children with other people. Some rarely allow their children to be cared for by others, because when the child is cared for by other people who are not the close mothers' friends, sometimes the children are susceptible to do bad things such as being rude and saying bad words. It reminds them that prison is known as a place for bad people and criminal labels.

\section{Social Construction of Good Mother}

Being a mother is a positive part of forming pleasure and part of identity, which also a social control of women. For women and children, especially in prisons, nurturing their children is a major component of their identity. However, at the same time, the expectations and social burdens of parenting reinforce oppressive feminist ideas, including self and need a sacrifice that is more personal for the women. The naturalization assumptions about masculinity and femininity related to gender performance standards strengthen the construction of being a mother. ${ }^{15}$ A person's ability to nurture their children must then be under social expectations and personal desires, which ultimately

\footnotetext{
${ }^{15}$ Carol Smart, "Criminological Theory: Its Ideology and Implications Concerning Women," in Law, Crime and Sexuality: Essays in Feminism (London: SAGE Publications, 1995), 16-31.
} 
depend on someone's access to time, financial, health, and social support resources. This proportion is a challenge for mothers, especially mothers in prison, who must negotiate the care of their children to be a good mother. The definition of good here can be seen from their viewpoint as mothers or both according to the environment and other people.

Imprisoned mothers face difficulties in their roles as mothers and face enormous challenges for their identity as mothers. ${ }^{16}$ Of the eight interviewees in this study, they all said they were eager to be good mothers, but because of their situation in prison, raising children and getting pregnant in prison, they thought that they are not good mothers yet. It is uttered when they were questioned about their idea of good mothers. Before answering, they fall silent for a moment, and sometimes their eyes began to teary over. As Saras, the eighth interviewee stated as follows:

"What should I say ... for me (good mothers are those) who really taking care and nursing their children. Always be by their children sides, how should I put it .... accompanying the children, being by their side. I am far from a good mom. I am disobedient, I fight with my children. I have big ego. Like, for example, I have children, and sometimes the children are stubborn, so do I. So, it's like "up to you, do whatever you want, I don't care, I already said it and you don't listen". I don't yield to my child". (Mrs. Saras/SU8/26/08/19).

The sixth interviewee, Rina, also agreed with Saras, she even becomes too emotional when talking about the concept of a good mother. She not only thinks of his role as a mother who later has to raise her child in prison but also thinks of her role as a mother whose child is outside the prison and cared for by her relatives.

"(Silence) (wiping tears with a tissue) Well ... a mother who is always there for her child to be there at any moment, now I'm far from the image of a good mother, especially for my child who is outside the prison. I feel bad for him, who has to be taken care of by my sibling. " (Rina/SU6/23/08/19)

Reska, the seventh interviewee, said that she was confused by the concept of a good mother. She said that she was not a good mother, since she had to ask for her mother to help in taking care of her three children during her imprisonment. Although she knows the condition of her old mother, she has no

${ }^{16}$ Brenda Geiger and Michael Fischer, "Naming Oneself Criminal: Gender Difference in Offenders' Identity Negotiation," International Journal of Offender Therapy and Comparative Criminology49, no. 2 (2005): 194-209, https://doi.org/10.1177/0306624X04270552. 
other choice but to ask for her mother's help. Nevertheless, as the mother of her three children, she wants to fulfill the needs of theirs and be there for them.

Unlike the others, the fifth interviewee, Nisa, also said that she could not yet be categorized as a good prospective mother to her child later. She thinks that what happened to her at the moment makes her unable to become a decent and good mother. Become pregnant without wedlock, and her status as a prisoner who commits theft makes her no longer hope to be called as a good mother.

Ikemoto ${ }^{17}$ explains the stereotypes applied to women who are classified as "bad" or "unfit" mothers. They are having low education levels, not impressive, easily influenced by simple religious dogmas, get pregnant because of promiscuity and irresponsibility. She opposes the authority, even though the Government has good intention. She is stupid, strange, and not reliable. She does not know what is best for her. Those characteristics are especially assumed to be applied for poor women, black women, Hispanics, Asians, and poor. The character mentioned by Ikemoto is relevant to the condition of the interviewee of this study.

Many imprisoned mothers do not have qualities that are usually associated with 'good' parenting, such as emotional control, reasoning skills, and adherence to non-physical punishment methods. ${ }^{18}$ A short opinion is in line with the findings in this study.

"I have ... sometimes I feel tired, very tired. I was not feeling well too. He (the child) is not fussy anyway, .... he cried loudly. I don't know how it turns out this way ... I go too far by pinching him. After that he vomit, oh.. I should not do that". (Mrs. Miftah / SU1 / 20/08/19).

The first interviewee stated that being in prison makes her have a more unstable emotional condition compared to mothers who do parenting outside the prison. Mothers who are in prison cannot always stay calm, especially in controlling their emotions.

\footnotetext{
${ }^{17}$ Lisa C Ikemoto, "Furthering the Inquiry: Race, Class, and Culture in the Forced Medical Treatment of Pregnant Women," Tennessee Law Review 59, no. 3 (1992): 487-517, http://www.ncbi.nlm.nih.gov/pubmed/11652636.

18Joann Wu Shortt et al., "Project Home: A Pilot Evaluation of an Emotion-Focused Intervention for Mothers Reuniting with Children after Prison," Psychological Services 11, no. 1 (2014): 1-9, https://doi.org/10.1037/a0034323.
} 
Poor quality of parenting related to emotional control was also found in the third interviewee, Mrs. Margaret. She once hit her son when he was in a fussy mood and did not want to stay calm, whereas she had just finished doing a korpe (working in prison, like washing clothes for others). There is an ambivalence that arises in Mrs. Margaret when her child played with other fostered citizens then accidentally fell, and it caused bruises and bumps on the child's head, even bleeding. The accident made Mrs. Margaret feel sad and very sorry. She regretted leaving her child with someone else when she had to work in prison. She was in a dilemma about the option to work to earn money for the needs of herself and the child in prison, while on the other hand, she could not give full attention to her child.

In the fourth interviewee, the information related to emotional control in the childcare process was not very visible because, during the interview, Mrs. Asti had just given birth to her eighth child, who at that time was one month old. The fifth, sixth, and seventh interviewees talked more about the process of their pregnancy while in prison. The last interviewee could not tell much about the parenting process she did in prison. It was due to the condition after giving birth. The child was immediately brought home by her parents to be nursed at home.

Social construction idealizes a woman must be able to be a good mother to her children in any condition. Unluckily, it contrasts with female prisoners/ convicts who consider themselves far from the criteria of being a "good" and "proper" mother. However, they still try to be mothers who could provide the needs of their children who are growing in prison. They sometimes are reluctant to give hugs, affections of love, and moral guidance to their children and teach them good behaviors.

\section{The Figure of Father in Parenting Practices in the Prison}

The Pondok Bambu Detention Center in East Jakarta is a particular prison for women. It has more female officers. Many male officers are placed at the front building for security and guarding to check the visitors or guests that will enter the detention center. It is quite challenging to find a male figure in a detention center, other than at the front entrance of the detention center. Starting from the guard, to the cooks in the kitchen are all women. The detention center also employs the fostered resident to help provide the food 
every day for other fostered prisoners. Practically, the process of parenting in prison does not have any male or father figures, just like the ideal concept of nursing the children outside the prison with a harmonious and ideal family situation.

Seven of the eight interviewees in this study said that the figure of the father in parenting practices is important. Although, in reality, the practice of parenting in prison did not have the role of the father at all, the seven of them still considered the role of the father is important. However, two of seven interviewees who thought the figure of the father was important did not want to bring the child and his father together. Nisa had her reason for not letting her unborn child to his father since there was a weird feeling in it. She thought that the father of her child was not a responsible person, a man who did not care about the hardships faced by Nisa in prison. According to Nisa, he was the one who should be responsible for how Nisa ended up in prison. The man did not send money for Nissa's living expenses while pregnant in prison.

Saras was also reluctant to bring her son and his father together since she and her husband were in the process of divorce. At first, Saras asked to fix the relations with her husband, but her husband refused it and chose to live with another woman. Saras claimed that it was not a problem if one day later, her child accidentally meets his father since they lived in the same neighborhood and close to each other, as long as her child was not brought home by his father.

Mrs. Margaret openly said that four of her children did not need a father figure in their life, especially for her youngest son, who is currently being nursed in prison. She reasoned that her husband did not have any contribution to hers and her children's life. He was also an irresponsible husband since, during the interview, he was also being prisoned. Mrs. Margaret felt that she was able to take care of her children without the figure of the father, even though she still needed her family to help her nursing the children outside the prison. She also thought she was able to fulfill the needs of her children. Margaret did not want to bring her child with their father together since, after all this time, her children spent more time with her.

The unpleasant experiences of their past with other people makes them think that they do not need a father figure both inside and outside the prison.

On the other hand, Miftah, Mrs. Yuni, Mrs. Asti, Lina, and Reska said that their children really needed the figure of the father. Even though the practice of 
parenting done in prison was not accompanied by a figure of the father, they claimed that after leaving the prison, they would bring their children to meet their father. Miftah and Rina were unable to bring a father figure to their children since their husbands also had to serve in prison because of the same case as them. Their prisons were far apart, and it was not easy for them to meet each other. They only occasionally communicated with each other by telephone to ask how the child was doing.

Miftah claimed that due to the lack of communication with her father, and the lack of male figure in the Pondok Bambu Detention Center, her one year two months old daughter called the mosque staff with the nickname "yayah".

"Wow, that's the hardest part... now she calls the men here papah. She was taught by friends, I think. In the mosque, there is a male spiritual staff and she calls him father. Because of the habit of calling this man as father, that man as dad ... so my daughter often says yayah yayah ... later when she meets her father, what should I say? Her father must be a stranger for her". (Mrs. Miftah / SU1 / 20/08/19)

Miftah's daughter also called other fostered prisoners who dress up in male style as papah. The case experienced by Miftah and her daughter shows the need for dual parenting in childcare practices, especially for children under the age of two years old who are experiencing the golden age stage. The dual parenting method between mother and father can not be applied in the prison since they have to serve their sentence in accordance with applicable regulations.

Nancy Chodorow claims dual parenting as important parenting. Chodorow puts the term of parenting in mothering activities. Parenting is considered to represent the idea of how both parents should both contribute to raising their children. The term of parenting that Chodorow initiated not only explains how a child is educated but also explains that patriarchal stereotypes must be eliminated in the values adopted in a family. Mothering which is transformed into parenting is not merely able to change the culture in viewing the concept of women, since the main problem is not about the term used, but the actualization. ${ }^{19}$

\footnotetext{
${ }^{19}$ Iqraa Ruli Aprilia, "Budaya Pemerkosaan dalam Sudut Pandang Feminisme Psikoanalisis: Opresi terhadap Kepribadian Anak Perempuan," in Konferensi Internasional Feminisme: Persilangan Identitas, Agensi dan Politik (20 Tahun Jurnal Perempuan) Oakarta: Yayasan Jurnal Perempuan,
} 
The figure of the father was also very needed by the one-year-old son of Mrs. Yuni. Mrs. Yuni said that her son did not want to be carried by his father when his father visits him in prison. The rejection of Mrs. Yuni's son was not without reason because he was not familiar with the figure of a man in his life. Since the time he was born, he was used to seeing his mother's face all the time.

"Once ... he was carried by his father however, since there were no men here so... he didn't want to be carried by his father. He was crying ... "this is dad"... he didn't want to and kept crying. So, I told my husband to come here often. Come here ... I didn't ask for anything as long as he is willing to come. Sometimes we rely on people outside the prison for any business ....". (Mrs. Yuni / SU2 / 20/08/19)

Chodorow also believes in this phenomenon, a viewpoint about mothers and childcare often attached only to women. Since a child suckles from his mother, women should also nurse their children. This viewpoint about women who take care of their children is considered a social structure. ${ }^{20}$ Therefore, the understanding of the role of mothers and fathers becomes a culture that is deliberately repeated to the children.

\section{Future of the Children after Two Years Old}

Points (3) and (4) Article 20 of Government Regulation No. 32 of 1999 about the Requirements and Procedures for the Implementation of Fostered Prisoners of Detention, states that the children of female prisoners who are taken into prisons or born in the prisons can be provided with supplementary food according to doctor's instructions, up to the age of 2 (two) years old and if they have reached 2 (two) years old, they should be handed to their father or relatives, or other parties with the consent of his mother and made in one statement report.

This study also discusses how a female fostered resident of Pondok Bambu Detention Center, who was the interviewee of this study, behaved towards their child, who was more than two years old in prison. Based on the government regulations, it is clear that if a woman becomes a fostered resident, she may take her children into the prison even when they were not born in

2016), 1853-76, https://www.jurnalperempuan.org/uploads/1/2/2/0/12201443/prosiding final.pdf.

${ }^{20}$ Nancy Chodorow, The Reproduction of Mothering: Psychoanalysis and the Sociology of Gender (Berkeley \& Los Angeles: University of California Press, 1978). 
prison. However, when the writer interviewed the midwife who served in the Pondok Bambu Detention Center, the officers said that the only children who could be nursed in the Detention Center were the children who were born in the Detention Center. If during the arrest process and undergoing punishment period someone has a child under the age of two years old, then the child is not allowed to enter the prison for the process of parenting. This was done for the health reasons; the detention center official said that when the child who was outside the prison had to enter prison with his mother, the official was worried that it would affect the child's health, both physical and mental. However, when someone is serving a sentence while pregnant and is about to give birth, she will be given the choice of whether she wants to keep her child in prison or entrust her child to the other family members.

Among the eight interviewees, Mrs. Miftah was the lucky one, since she and her child, who was one year and two months old, would be released/ finished the detention period in few weeks after the interview was conducted. Mrs. Miftah did not experience the same worrisome as other interviewees because she and her child would complete the period of detention together before the child turns two years old.

Mrs. Yuni, Mrs. Magdalena, and Mrs. Asti are prisoners of drug abuse cases. The three of them have longer prison term than fostered prisoners with fraud cases. On average, they have to serve about four years sentence period. It means, when their children turn over two years old, they should first hand their children to the other family members or relatives who want to help take care of their children's lives outside the prison. Meanwhile, they have to complete their sentence period.

Apparently, there are interesting experiences that they tell after giving birth. Not much different from the story in the background of this study, Mrs. Yuni had an experience in which her child was asked by the other fostered residents who had finished their period of detention. During their sentence period, those inmates knew Mrs. Yuni's child. However, Mrs. Yuni refused to give her child to the person. The person offered to take care of Mrs. Yuni'schild, and later, when Mrs. Yuni was released from prison, she could take her child back.

Many people were interested in taking care of Mrs. Mardalena's and Mrs. Asti's child, but Mrs. Mardalena refused it. They all refused with a similar reason 
that they preferred their children to be with them since their children were solaces for them. To be with their children in prison makes them happier without having to worry about their sentence period.

The interviewees who were pregnant, Nisa, Rina, and Rezka, also said that they wanted to take care of their children, and if later their children turned more than two years old and they could not be together anymore, they let their children to be nursed by their families. However, for Saras, after giving birth, she handed her child to her father.

"Then my father said, just bring him home, he will be my company at home, right? I said no and want to keep him with me since it won't be for a long period of time. Here we can keep our children until they turn two years old. So I said just let him be here. But it is no because it will be so complicated. What if the baby is sick or something bad happened. Actually, we also get some services here. The immunizations are free but it's complicated". (Mrs. Saras/SU8/26/08/19)

This indicates the power relation between Saras and her parents, which in this case is her own father. Saras does not have the power to her ownership, namely sananak. In this case, power is the key element in discussing this discourse. In general, power is understood and discussed as the influence that affects a person or institution to impose their will on other parties. Foucault's thought used to critically analyze the cultural construction tends to marginalize the role of women and to use it as a tool to dismantle the symbol of patriarchal power that is implanted and packaged through myths and stereotypes. ${ }^{21}$

Gender hierarchy also creates a power relation in which men claimed to be more powerful than women. This was also applied by Saras's father, who, at that time, had two children and was married. As she was considered unable to take care of her own children, her father took over the nursing process of Saras's child. In the case of Saras, she was unable to refuse his father's demand even though at the beginning, she said that she wanted to take care of her own child in prison. The character and personality of Saras, who is self-centrist with low educational background, affects the power relationship experienced by Saras and her father in terms of childcare practices.

\footnotetext{
21Pinky Saptandari, "Dilema Perempuan Buruh Migran dalam Peran Meningkatkan Kesejahteraan Keluarga," Jurnal Perempuan, 2016, 334-59.
} 
Choosing to nurse their own children until the age of two years old or hand the children to the other family members or to third parties can all be influenced by the power relation between the imprisoned mother with her partner, with the family or with other parties who are considered to have more power in term of the finance to nurse the children.

\section{Conclusion}

The practice of parenting by imprisoned women, especially those who bring their children and those who are in the state of pregnancy, is inseparable from worry and anxiety over the feelings of the woman's inability to nurse their children in prison. The concern then influence the perspective of imprisoned mothers in viewing the concept of a good mother. Social construction from the society which considers a good mother is a mother who is always there for her children, and the demands from the society that keeps increasing make things worse. The eight interviewees in this study did not own the concept of an ideal mother. They all felt that they did not deserve to be called good mothers even by their own children.

In addition, emotional support is also needed for imprisoned mothers to continue to be able to do the parenting process. Fellow inmates and prison officials can provide emotional support. Relationships with families, especially with husbands or other extended family members, are also very influential in the parenting process. This research shows that the parenting process is not only done in prison but also outside the prison by other relatives who help the inmates take care of their children.[s]

\section{References}

Aprilia, Iqraa Ruli. "Budaya Pemerkosaan dalam Sudut Pandang Feminisme Psikoanalisis: Opresi terhadap Kepribadian Anak Perempuan." In Konferensi Internasional Feminisme: Persilangan Identitas, Agensi dan Politik (20 Tahun Jurnal Perempuan), 1853-76. Jakarta: Yayasan Jurnal Perempuan, 2016. https://www.jurnalperempuan.org/uploads/1/2/2/0/ 12201443/prosiding_final.pdf. 
Baldwin, Lucy. "Motherhood Disrupted: Reflections of Post-Prison Mothers." Emotion, Space and Society 26 (2018): 49-56. https://doi.org/10.1016/ j.emospa.2017.02.002.

Cecil, Dawn K., James McHale, Anne Strozier, and Joel Pietsch. "Female Inmates, Family Caregivers, and Young Children's Adjustment: A Research Agenda and Implications for Corrections Programming." Journal of Criminal Justice 36, no. 6 (2008): 513-21. https://doi.org/10.1016/j.jcrimjus.2008.09.002.

Chodorow, Nancy. The Reproduction of Mothering: Psychoanalysis and the Sociology of Gender. Berkeley \& Los Angeles: University of California Press, 1978.

Geiger, Brenda, and Michael Fischer. "Naming Oneself Criminal: Gender Difference in Offenders' Identity Negotiation." International Journal of Offender Therapy and Comparative Criminology 49, no. 2 (2005): 194-209. https://doi.org/10.1177/0306624X04270552.

Heidensohn, Frances. "Gender and Crime." In The Oxford Handbook of Criminology, edited by M. Maguire, R. Morgan, and R. Reiner. Oxford Handbooks. Oxford: The Oxford University Press Incorporated, 2007.

Hitchcock, J. E., P. E. Schubert, and S. A. Thomas. Community Health Nursing: Caring in Action. New York: Thomson Learning Inc., 2003.

Ikemoto, Lisa C. "Furthering the Inquiry: Race, Class, and Culture in the Forced Medical Treatment of Pregnant Women." Tennessee Law Review 59, no. 3 (1992): 487-517. http://www.ncbi.nlm.nih.gov/pubmed/11652636.

Lee, Jenifer Arnett. "Women Prisoners, Penological, Interest, and Gender Stereotyping: An Application of Equal Protection Norms to Female Inmates." HeinOnline, 2001. https://heinonline.org/HOL/LandingPage? handle=hein.journals/colhr32\&div=11\&id=\&page $=$.

Lois, Jennifer. "Emotionally Layered Accounts: Homeschoolers' Justifications for Maternal Deviance." Deviant Behavior 30, no. 2 (2009): 201-34. https://doi.org/10.1080/01639620802069783.

Luther, Kate, and Joanna Gregson. "Restricted Motherhood: Parenting in a Prison Nursery." International Journal of Sociology of the Family 37, no. 1 (2011): 85-103. https://www.jstor.org/stable/23029788.

Moore, L., and P. Scraton. The Incarcerated of Women: Punishing Bodies and Breaking Spirits. London: Palgrave Macmillan, 2014. 